\title{
LELLIOTTIA NIMIPRESSURALIS (CARTER 1945) BRADY ET AL. 2013 - THE CAUSATIVE AGENT OF BACTERIAL DROPSY OF COMMON OAK (QUERCUS ROBUR L.) IN UKRAINE
}

\author{
I.M. Kulbanska , M.V. Shvets ${ }^{2}$, A.F. Goychuk', \\ L.H. Biliavska ${ }^{4}$, V.P. Patyka ${ }^{3}$ \\ ${ }^{I}$ National University of Life and Environmental Sciences of Ukraine, \\ 19 General Rodimtsev Str., Kyiv, 03041, Ukraine \\ 2Polissia National University, \\ 7 Staryi Blvd, Zhytomyr, 10008, Ukraine \\ ${ }^{3}$ Zabolotny Institute of Microbiology and Virology, NAS of Ukraine, \\ 154 Acad. Zabolotny Str., Kyiv, 03143, Ukraine \\ ${ }^{4}$ Poltava State Agrarian Academy, \\ 1/3 Skovoroda Str., Poltava, 36000, Ukraine \\ e-mail: patykavolodymyr@gmail.com
}

The article presents the symptomatic characteristics of vascular-parenchymal bacteriosis, which is quite common on forest woody plants, caused by the causative agent of bacterial dropsy. It was shown that a characteristic feature of this bacteriosis is the formation of various shapes and sizes of ulcers, in the places of formation of which there is a release of a dark, almost black, exudate. It is emphasized that during the study of the vascular system of common oak trees, its dark coloration is noticeable. Now there is a chronic course of the disease with the presence of dieback of individual branches in the crown. It was established that the causative agent of bacterial dropsy is Lelliottia nimipressuralis; its physiological and biochemical characteristics are given. The aim of the work is the bacteriological study of wood samples with typical signs of bacterial dropsy, study of morphological, cultural and biochemical properties of the causative agent of bacterial dropsy of oak. Methods. Classical microbiological, phytopathological, biochemical, statistical methods were uses in the work. If a bacterial dropsy was suspected, diagnostic methods were combined, with the help of which the etiology of the disease was established: an accurate analysis of symptoms; a thorough microscopic examination of the affected parts of plants; isolation and identification of the pathogen using NEFERMtest24 MikroLaTE, ErbaLachema, API 20E test systems and the like. Results. We have noted the habitual manifestations of the bacterial dropsy of the common oak. From the lesion, where dark brown areas of wood appeared under the bark in the area of the ulcer against the background of healthy light-colored wood, isolated bacterial isolates were identified by morphological and physiological-biochemical properties as Lelliottia nimipressuralis (Brady et al. 2013) - the causative agent of bacterial dropsy of oak (now Enterobacter nimipressuralis). It was found that isolates from common oak, like the collection strain E. nimipressuralis 8791, are gram-negative. It was shown that the studied bacteria are facultative anaerobes and use glucose both under aerobic and anaerobic conditions. They do not form gelatinase and protopectinase. Exhibit a positive VogesProskauer reaction. Bacteria use glucose, arabinose, rhamnose, amygdalin, and melibiose as the only source of carbon nourishment. The bacteria do not use inositol and sorbitol. They do not form indole and hydrogen sulfide $\left(\mathrm{H}_{2} \mathrm{~S}\right)$, but are capable of reducing nitrates. They contain arginine dehydrolase, ornithine decarboxylase, $\beta$-galactosidase, but not lysine decarboxylase, and urease. Conclusions. It has been established that the diseases that we discovered are, by all symptomatic signs, a systemic, vascular-parenchymal bacteriosis, known as bacterial dropsy of oak, which affects all tissues, plant parts and generative organs at all stages of ontogenesis. According to the morphological, physiological and biochemical properties of bacterial dropsy isolated by us during the research, we identified the causative agent of bacterial edema of oak-Lelliottia nimipressuralis (Carter 1945).

Keywords: Lelliottia nimipressuralis, common oak, phytopathogenic bacteria and fungi, sudden death, etiology, pathogenesis, bacterial dropsy. 
The phytosanitary state of forests, as a result of the negative impact of a complex of factors of abiotic and biotic origin, has deteriorated sharply. Over the past 5-7 years, throughout Ukraine, there has been massive dieback out of most forestforming species (Scots pine, European spruce, common ash, common oak, common hornbeam, silver birch), in some regions the situation has become catastrophic. This process takes on traits of a global nature. Now the total area of drying out forests is more than 400 thousand hectares, of which plantations of Scots pine - 222 thousand hectares, European spruce - 20 thousand hectares, common oak -100 thousand hectares, and other plantations -60 thousand hectares [1].

The situation with the phenomenon of «accelerated» dieback of oak is very alarming. Every day there are new messages from practitioners of the forestry industry, indicating a massive and dynamic spread of pathological phenomena of unknown etiology in stands with the participation of common oak. In particular, foresters of Uzhhorod district in the Zakarpattia region report about dieback of oaks in local forestry (over 400 hectares of oak tracts died). Foresters of the Volyn and Khmelnytsky regions are very concerned $[2,3]$.

The accelerated dieback of Quercus robur L. is noted by foresters of the Kyiv region (in particular, in the state enterprise Fastivske forestry) [4].

Some assumptions have been made about the causes of this phenomenon, in particular, we are talking about climatic changes and hydrothermal stress, invasive infectious agents, and pests, but so far each of the theories requires scientific confirmation [5-8]. Researchers of oak associations are unanimous that common oak in recent decades has been characterized by reduced resistance and competitiveness, as well as accelerated dieback $[5,9]$. Also, scientists have repeatedly noted the cyclicality and established the chronology of this phenomenon, and the life cycle of oak stands alternates with periods of stabilization of the sanitary state and periods of accelerated dieback [5-7, 9-11]. In particular, the first direct information on the accelerated dieback of oak dates back to the $40 \mathrm{~s}$ of the $19^{\text {th }}$ century (mass death of natural oak forests in the Kharkov province [10]. At the same time, according to researchers of changes in the growth of oak in the forests of the Voronezh region, the years $1764-67,1774-78,1794-98$, 1811-19 were extremely critical years for common oak [12]. In general, over the past 100 years, there was at least three waves (periods) of extreme exacerbation of the pathological condition of the oak tree, which was accompanied by its massive dieback: 1911-1982, 1927-1946 and 1964-1983 (each wave lasted 19 years, the interval between them was 16 and 18 years) [7].

Among the researchers of the reasons for the sudden dieback of oak, supporters of bacterial $[13-15]$ and mycotic etiology can be distinguished $[5,7,16]$.

The phenomenon of «Sudden oak death» is widespread in Europe and the United States. The etiology is associated with the fungus Phytophthora ramorum Werres, de Cock \& Man in 't Veld (2001): kingdom Stramenopila; phylum Oomycota; class Peronosporomycetidae; order Pythiales; family Pythiaceae; genus Phytophthora [17]. The first mentions are associated with the mass dieback of oak plants dates from the 1990s and covered the forests of California, Great Britain and the Netherlands [17, 18]. The causative agent causes typical symptoms of infection (wounds, ulcers on the trunk, death of individual branches), except for common oak, in Q. falcata and Q. rubra [19] and other species of forest woody and adornment plants [20]. Now the range of affected plants is 109 species [21].

Also in the scientific literature related to the etiology of the mass dieback of oak cenoses, it is necessary to mention the fungus Ceratocystis fagacearum (Bretz.) Hunt. (syn. Chalara quercina, syn. Endoconidiophora fagacearum Bretz) (Microascales, Ophiostomataceae) as the causative agent of a systemic lethal oak disease called «wilt». The disease was first described in 1943 [22]. Subsequently, it became widespread in a number of US states: Minnesota, Texas, Pennsylvania and South Carolina. The causative agent affects about 20 species of oak, including Quercus alba, $Q$. borealis, $Q$. coccinea, Q. macrocarpa, and Q. vehtiina. The manifestation of the disease begins at the top of the tree. The tops of the leaves and their edges become bronze. The transition from green to dead tissue is often pronounced. Leaves curl and wither. Their color change from yellow to brown sometimes occurs along the leaf ribs. Soon after the first symptoms of the disease appear, the leaves begin to fall off (this process lasts from several days to several weeks). Following this, small shoots and branches begin to die off. Simultaneously with the symptoms on the leaves, brown streaks appear in the water vessels of the outer layers of sapwood colonized by the fungus. This is a consequence of the development of fungal colonies in the vasculars. Such vasculars are soon filled with a dark «gum- 
like» substance [8]. Separate studies have proven the role of oak bark beetles (Pseudopityophthorus spp.) in the transfer of Ceratocystis fagacearum spores [23].

There is information about mycological analysis of oak wood with dark vessels, in which the fungus Ophiostoma roboris Georgescu et Teodoru. was isolated [8].

Other researchers, in particular ShcherbinParfenenko, isolated and experimentally confirmed their involvement in the massive dieback of oak Plasmopara nigro-quercina Sczerbin-Parfenenko sp. n., Xanthomonas quercus Sczerbin-Parfenenko sp. n., Erwinia lignifilla Sczerbin-Parfenenko sp. n. and Erwinia multivora Sczerbin-Parfenenko sp. n. [24].

Research on the causative agents of bacteriosis of oak is not sufficiently studied. In some cases, only the name of the bacterium is given without any description, sometimes such a short description is given, it does not allow for identification at all. For example, Ludwig points out that the brown slime on the oak is caused by Micrococcus dendroporthos Ludw [16].

Yachevsky A.A. (1935) and Israelskyi V.P. (1952) indicate another bacterium found on oak Pseudomonas syringae von Hall. It is a polymorphic species that has synonyms: Bacterium cerasi (Griffin) Elliott, Pseudomonas citriputeale Sfapp. etc. [13, 25-27].

More than others, the Romanian scientist C.C. Georgescu paid attention to the study of bacteria on oak. In 1952, he pointed out that the following bacterial species were isolated from various damage to oak in the forests of Ploiesti: Erwinia valachica Georg et Bod, Erwinia valachica f. onaca, Erwinia gueieicola Georg, et Bod. [26].

The etiology, symptomatology and pathogenesis of bacteriosis of common oak, in particular the properties of the causative agent of bacterial dropsy, have been studied in detail in the works of Professor A.F. Goychuk [16, 26], on which our research is based.

In 2006, in some forestry enterprises of Belarus, located mainly in the southern part of the republic (Gomel, Komarinsky, Rechitsky, Svetlogorsk, Khoiniksky, etc.), the forest pathological service «Belgosles» noted the emergence of a new oak disease, which is similar in symptoms and signs to bacterial dropsy birch.

Materials and methods. Research work was carried out in the conditions of the State Enterprise
«Fastivske forestry», Kyiv region (Forest Compartment 97, Division 5, stand composition Quercus robur (80\%), Carpinus betulus (20\%), age -92 years, stand density -0.6 , site quality of forest $-\mathrm{I}$, average height $-25.5 \mathrm{~mm}$, average diameter $-33 \mathrm{~cm}$, and Forest Compartment 100, Division 1, area - 18.8 hectares, stand composition Quercus robur (100\%), Betula pendula, Acer platanoides, Prunus avium (less than 10\%), age -82 years, stand density -0.7 , site quality of forest $\mathrm{I}$, average height $-25 \mathrm{~mm}$, average diameter $36 \mathrm{~cm}$ ) in order to study the patterns of habitual manifestations of the pathology of the bacterial dropsy of the common oak, the distribution, differentiation and combination of pathological signs, their connections with the physiological state of trees. Samples of common oak wood with signs of bacterial dropsy were used for bacteriological analysis. In particular, for bacteriological analysis, we took material from affected wood (at the border with healthy tissue).

Reconnaissance and detailed lisopathological surveys of stands were performed with the participation of Quercus robur in accordance with SOU 02.02-37-476:2006 "Forest inventory trial plots. Line-intercept method" (2007). 17 model trees felled. 40 samples were taken for mycoand microbiological studies; 23 bacterial isolates were identified, we assigned them to the genera Pseudomonas (in particular, Pseudomonas sp., P. fluorescens), Pectobacterium (P. cartovorum), Xantomonas ( $X$. campestris), as well as 4 isolates of Lelliottia (L. nimipressuralis) (now Enterobacter nimipressuralis has become obsolete by the name of the causative agent of the bacterial dropsy of oak), although there is some disagreement on this in the literature.

Bacteriological analysis was carried out by homogenizing the plant material, followed by inoculation in Petri dishes on agar nutrient medium and growing in a thermostat at $28^{\circ} \mathrm{C}$ for $4-5$ days. For bacteriological analysis, we used specimens of common oak wood with signs of bacterial dropsy: 1 - gray area in wood - vascular lesion and 2 - dark brown affected area of wood against the background of healthy light-colored wood, spreads from the bark, ulcer on the bark (Fig. 3). Colonies of bacteria were selected for analysis and plated onto agar nutrient medium in test tubes. Morphological, cultural and biochemical properties of bacterial isolates were determined by conventional methods [28-31] and using test-system API 20E and test-systems NEFERMtest24, MikroLaTEST ${ }^{\circledR}$, ErbaLachema. 
Calculations and statistical data processing were carried out using Microsoft Excel computer programs.

Results. In the study region, we identified local foci of dieback of common oak, which on average cover 6-10 neighboring trees (Fig. 1a). On some specimens, the phenomenon of rarefaction (openwork) of crowns, as well as partial or complete defoliation and withering away of 12 annual shoots, which, at the same time, are black and curved, as if damaged by frost, was noted. On the trunks (mainly at a height above 1.5-2 m), cracking of the bark with streaks of liquid and mucus was noted (Fig. 1b). Liquid of dark color (brown, sometimes black) gassed with bubbles, with a typical smell of buttery-acid fermentation (Fig. 1c). In some areas, cracks turn into depressed necrotic wet wounds. If the outer bark layer is cut off, a wet black bast fiber is visualized, sometimes down to the cambium. In the latter case, an ulcer forms on the trunk. Ulcers can be of various shapes and sizes (usually oblong-oval in size from $3 \times 4 \mathrm{~cm}$ to $6-8 \times 30-35 \mathrm{~cm}$ ), single or numerous, located on different parts of a woody plant. Note that such wounds were relatively rare in the lower part of the trunk. Wet cancerous wounds and black streaks along the cracks in the bark are absolute external signs of bacteriosis.

At the same time, black streaks on the bark can occur due to the vital activity of Anisandrus dispar Fabr., but, in this case, the flight holes are clearly visible on the cut of the bark. There are also water shoots on the trunks, which are another direct evidence of bacteriosis affecting oak trees.
Also, when cutting model trees, we registered internal symptoms of the manifestation of bacterial dropsy of common oak. In particular, all models have a wet pathological nucleus of a round or stellate shape (Fig. 2a) with penetration into shoots and exit (along the core rays) into cracks and wounds under pressure of gases, which tear the wood tissue (Fig. 2b). In the affected tissues, soft rot develops with mucus, necrosis and tissue maceration.

Sometimes, instead of cancerous wounds in the sapwood, we noticed (after removing the bark) long brown stripes in the ball of the last growth ring. Immediately after removing the bark, they have a bluish coloration, clearly visible on fresh sapwood. In cross section, these brown stripes appear as spots of various sizes located along the vasculars. We noticed all the external signs of bacteriosis damage described above on mature oaks, regardless of the growth class and growing conditions. Thus, the disease identified by us for all symptomatic signs known from literary sources [14] is a systemic, vascular parenchymal bacteriosis, known as bacterial dropsy of oak, which affects all tissues (phloem, cambium, xylem), parts of the plant (branches, trunks, root system) and generative organs (flowers, ovary, fruits, seeds) at all stages of ontogenesis, including self-seeding and seedlings.

From the lesion with symptoms 2 , two isolates of bacteria were selected, the colonies of which were gray. The selected bacterial colonies were similar to those of the collection strain E. nimipressuralis 8791 . Seven bacterial isolates were isolated from both types of oak lesions and selected for research.
A

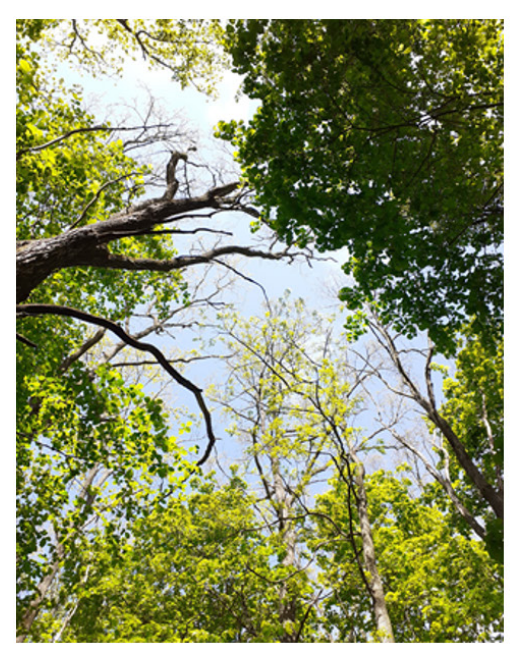

B

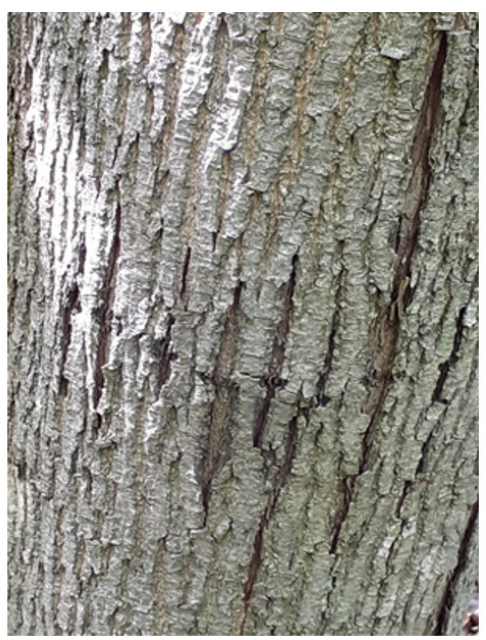

C

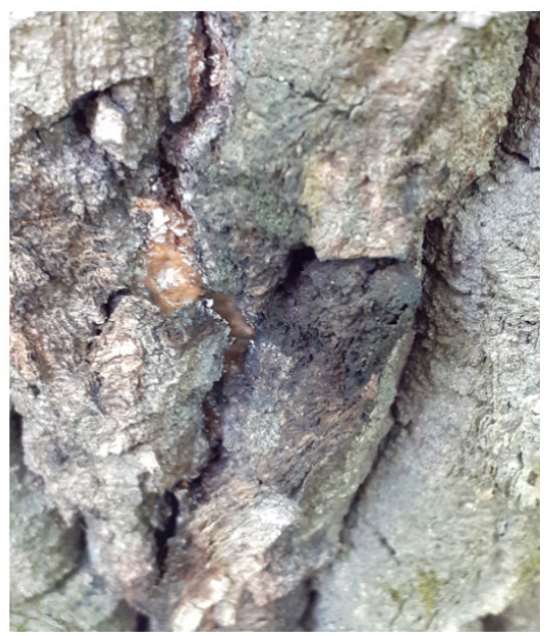

F i g. 1. External symptoms of the manifestation of bacterial dropsy of common oak: a - the focus of death of trees; $b$ - cracks on the trunk (in the center); the outflow of bacterial exudate (right) 

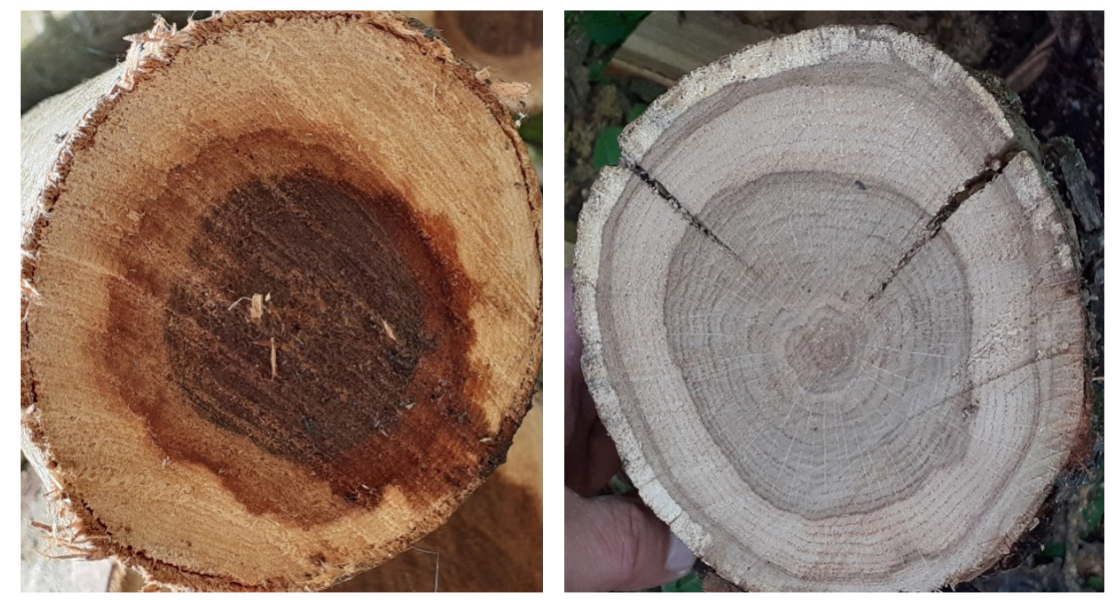

F i g. 2. Internal symptoms of bacterial dropsy of common oak: wet pathological nucleus (left); cracks in the trunk (right)

Reconnaissance and detailed lisopathological surveys of green spaces with the participation of Quercus robur were carried out according to SOU 02.02-37-476: 2006 "Forest Inventory Trial Plots" (2007). 17 model trees were felled. 40 samples were taken for myco- and microbiological studies; 23 bacterial isolates were obtained, we assigned them to the genera Pseudomonas (in particular, Pseudomonas sp., P. fluorescens), Pectobacterium ( $P$. cartovorum), Xantomonas ( $X$. campestris), as well as 4 isolates of Lelliottia (L. nimipressuralis) (now Enterobacter nimipressuralis has become obsolete by the name of the causative agent of the bacterial dropsy of oak), although there is some disagreement on this in the literature.

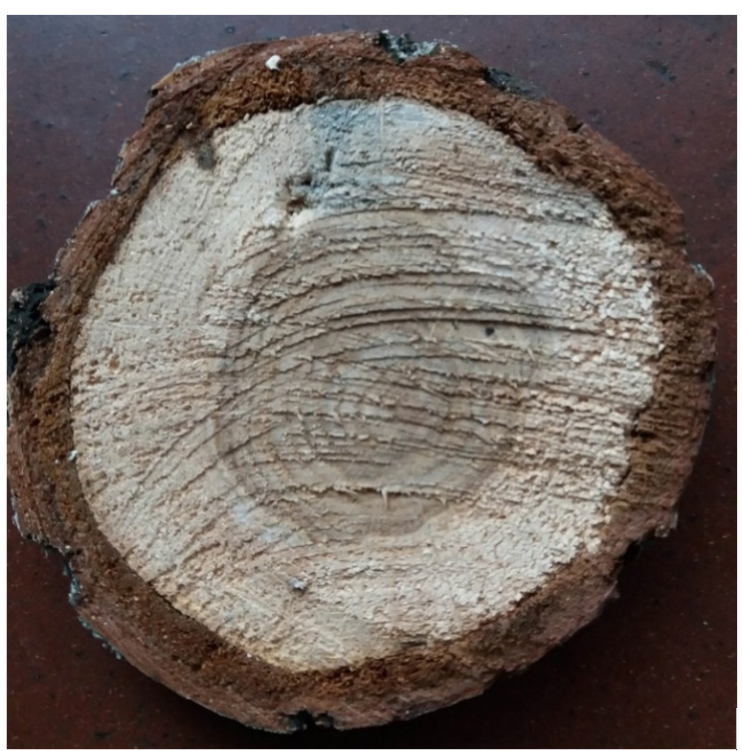

F i g. 3. Disease of oak: «1» - gray area in wood; «2» - the formation of a brown color in oak wood in the area of the ulcer
It is known that Enterobacter nimipressuralis Carter 1945 (collection strain Erwinia nimipressuralis 8791) is the obsolete name of Lelliottia nimipressuralis (Carter 1945) Brady et al. 2013), it was used by us for comparison with strains isolated from oak tissues in order to establish similar and different morphological and anatomical signs and physiological and biochemical characteristics (to confirm or refute our assumptions about the causative agent of the disease, which was identified by us as a bacterial dropsy based on typical visual signs).

Characteristics of isolates from type 1 lesions. The bacteria were Gram stained and tested for oxidase. Four isolates from type 1 lesion (gray zone) were oxidase-negative (Tabl. 1). Studies of the biological properties of isolates were performed using two test systems - NEFERMtest24 MikroLaTES (Fig. 4, 5; Tabl. 1) and test system API 20 E (Fig. 6, Tabl. 2) in order to determine more characteristics of bacteria needed for their identification.

Table 1 provides information on 4 types of isolates that were close to the collection strain in physiological and biochemical characteristics and will be used in further studies.

It was revealed that the isolated bacteria do not use lactose and glucose (in anaerobic conditions), like bacteria of the genus Pseudomonas. But isolated oxidase-positive bacteria cannot be phytopathogenic. On the other hand, these bacteria reduce nitrates and have positive Voges-Proskauer reaction, like bacteria of the genus Pectobacterium (Erwinia). However, according to the complex of investigated characteristics, these bacteria cannot be attributed to bacteria of the genus Pectobacterium 
(Erwinia), since they do not use glucose in anaerobic conditions. So, bacteria isolated from the inner tissues of oak are not causative agents of bacterial blight, but are saprotrophic bacteria.
Characteristics of isolates from type 2 lesions. The identification of 2 isolates was carried out by studying their characteristics and comparing them with the collection strain E. nimipressuralis

\section{Table 1}

\section{Physiological and biochemical properties of isolates from oak (symptom 1) using the TNEFERMtest24 MikroLaTEST ${ }^{\circledR}$, ErbaLachema test-system}

\begin{tabular}{|l|c|c|}
\hline Symbol & Test & Results* \\
\hline OXI & Oxidase & + \\
\hline URE & Urease & + \\
\hline ARG & Arginine & + \\
\hline ORN & Ornithine & + \\
\hline LYS & Lysine & + \\
\hline AAM & Acetamide & - \\
\hline$\beta G L$ & $\beta$-glucosidase & + \\
\hline NAG & Simpson Citrate & - \\
\hline SCI & Lactose & + \\
\hline LAC & Mannitol & + \\
\hline MAN & Trehalose & + \\
\hline TRE & Xylose & - \\
\hline XYL & Arabinose & - \\
\hline ARA & $\alpha$-galactosidase & + \\
\hline$\alpha G A$ & $\beta$ - galactosidase & + \\
\hline$\beta G A$ & Malonate & - \\
\hline MAL & Galactose & + \\
\hline GAL & Maltose & + \\
\hline MLT & Cellobiose & - \\
\hline CEL & Saccharose & + \\
\hline SUC & Inositol & + \\
\hline INO & $\gamma$-glutamyl transferase & + \\
\hline$\gamma G T$ & Phosphatase & - \\
\hline PHS & Esculin & \\
\hline ESL & Glucose (anaerobic) & + \\
\hline & - & + \\
\hline
\end{tabular}

$*+$ the presence of the property, - the absence of the property.

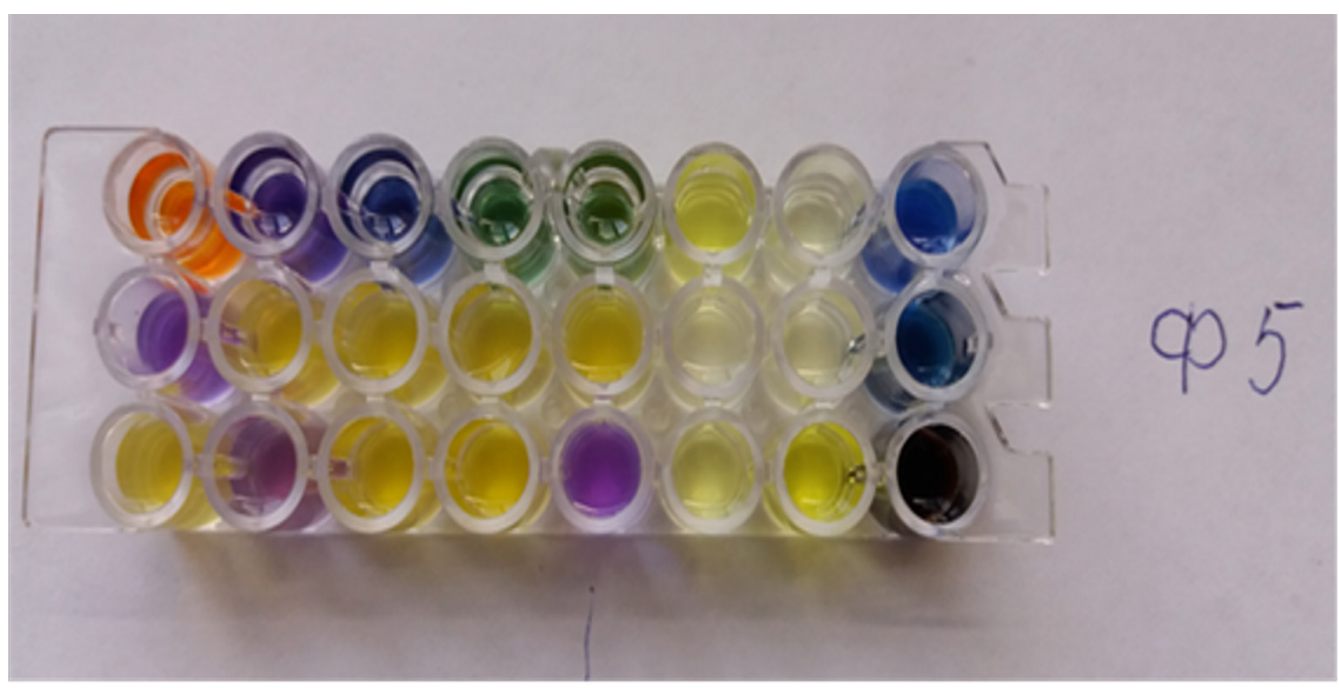

F i g. 4. Characteristics of $\Phi 5$ isolate for the use of the NEFERMtest24 MikroLaTE test system 
8791 and the properties of bacteria given in the bacterium indicator [11] (Tabl. 3, Fig. 7). The data in tables 1, 2, 3 confirm that all strains isolated by us (in terms of physiological and biochemical characteristics) were similar to the collection strain E. nimipressuralis 8791 and so are similar to each other.

It was found that isolates from common oak, like the collection strain E. nimipressuralis
8791, are gram-negative rods. The bacteria tested are facultative anaerobes, use glucose in both aerobic and anaerobic conditions (Fig. 5). All investigated bacterial isolates do not form gelatinase and protopectinase, have a positive Voges-Proskauer reaction. Bacteria use glucose, arabinose, rhamnose, beckon, amygdalin, and melibiose as the only source of carbon nourishment (Fig. 5).

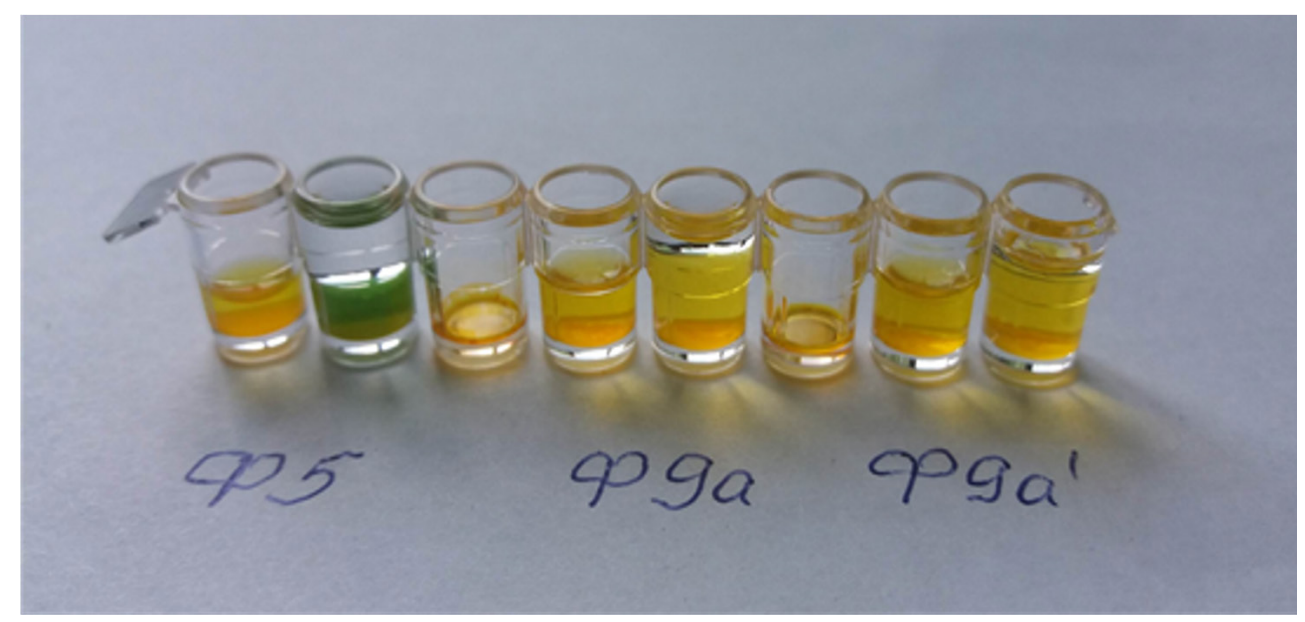

F i g. 5. Growth of bacterial isolates on a medium with glucose (anaerobic) for using the NEFERMtest24 MikroLaTEST®, ErbaLachema test system: receptacles 1, 4, 7 - control, bacterial growth in aerobic conditions; receptacles $2,5,8$ - bacterial growth under the oil (anaerobic conditions); Symbols Ф5, Ф9a, Ф9a' are isolates of pathogens of bacterial dropsy, which are directly used by us to characterize bacteria using test systems NEFERMtest24 MikroLaTE, ErbaLachema, API 20E, etc.

Table 2

Physiological and biochemical properties of oak isolates (symptom 1) (API 20 E test system)

\begin{tabular}{|l|c|}
\hline Tests & Results* \\
\hline Yellow pigment & - \\
\hline Reduction of nitrates & + \\
\hline Formation of $\mathrm{H}_{2} \mathrm{~S}$ & - \\
\hline Formation of indole & - \\
\hline$\beta$-galactosidase & + \\
\hline Arginine dehydrolase & + \\
\hline Lysine decarboxylase & + \\
\hline Ornithine decarboxylase & + \\
\hline The use of citrate & - \\
\hline Urease & + \\
\hline Tryptophan deaminase & + \\
\hline Voges-Proskauer reaction & + \\
\hline Gelatinase & - \\
\hline The use of: Glucose (anaerobic) & - \\
\hline Mannitol, inositol, sorbitol, rhamnose, saccharose & - \\
\hline Melibiose, amygdalin, arabinose & + \\
\hline
\end{tabular}

$*+$ the presence of the property, - the absence of the property. 


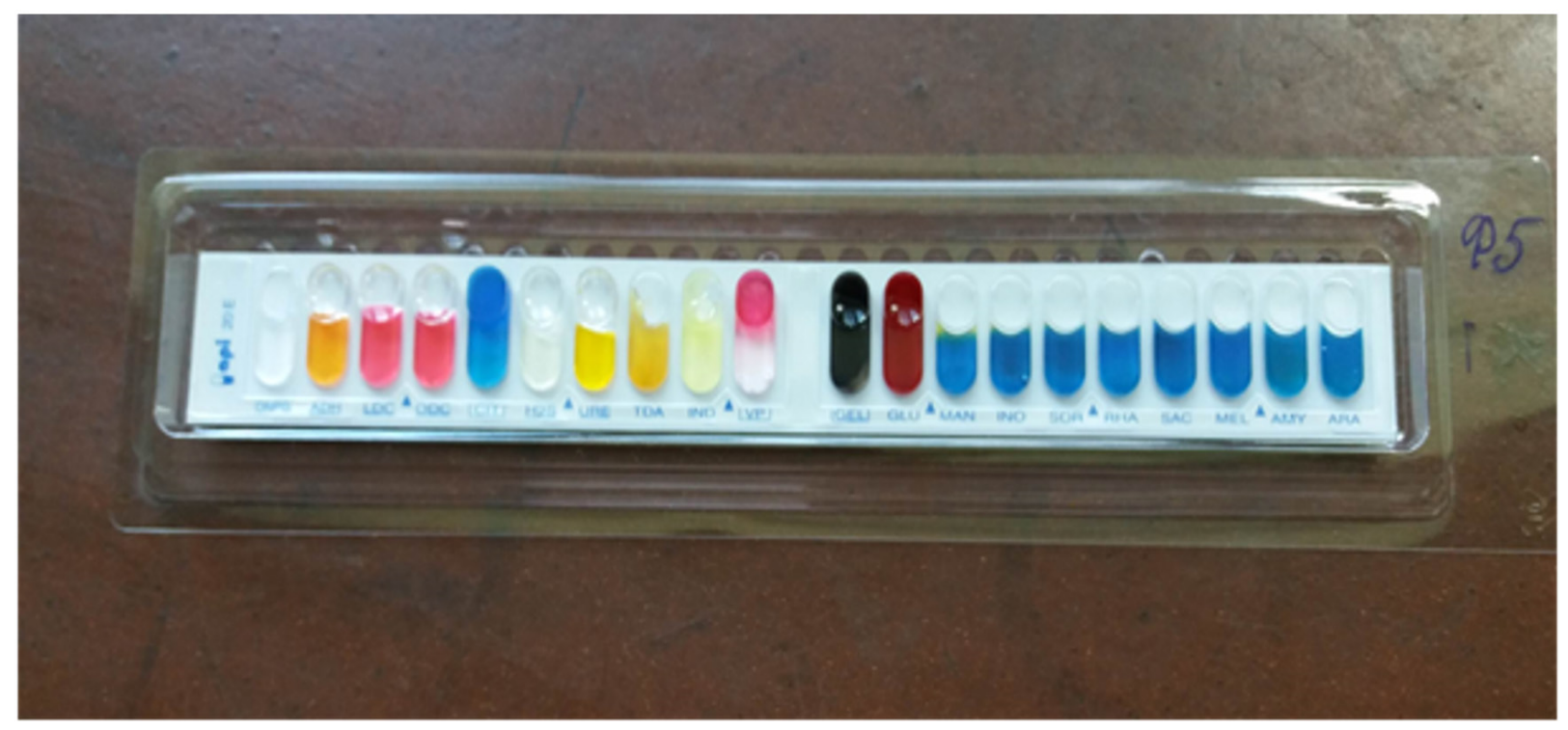

F i g. 6. Characteristics of $\Phi 5$ isolate using the API $20 \mathrm{E}$ test system

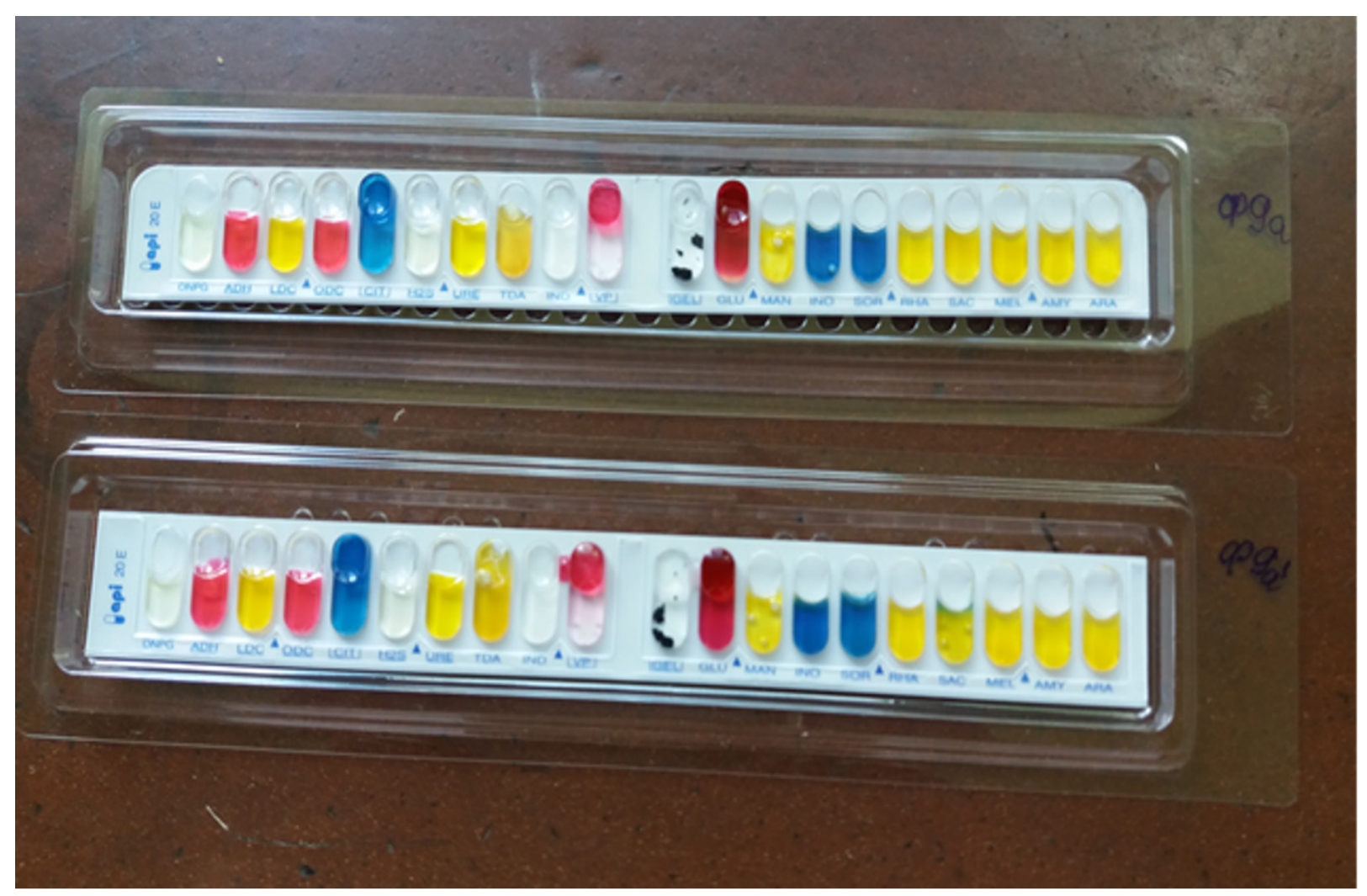

F i g. 7. Characteristics of $\Phi 9$ a and $\Phi 9 a^{1}$ isolates using the API $20 E$ test system

The bacteria do not use inositol and sorbitol citrate. They do not form indole and hydrogen sulfide $\left(\mathrm{H}_{2} \mathrm{~S}\right)$, but are capable of reducing nitrates. They contain arginine dehydrolase, ornithine decarboxylase, $\beta$-galactosidase, but not lysine decarboxylase, urease.

According to the complex of the investigated characteristics, bacterial isolates obtained from oak (symptom 2) are similar to the collection strain E. nimipressuralis 8791 and correspond to the properties given in the Bergey's manual of systematic bacteriology [32] for E. nimipressuralis.

Discussion. Now in forest plantations with common oak in Ukraine and the world, there is a massive and dynamic spread of pathological phenomena of unknown etiology. It is noted that in recent decades, oak forests are characterized 
Table 3

Morphological and biochemical properties of isolates from oak

\begin{tabular}{|l|c|c|}
\hline Tests & Bacterial isolates* & E. nimipressuralis 8791* \\
\hline Gram's staining & - & - \\
\hline Mobility & - & - \\
\hline Yellow pigment & - & - \\
\hline Oxidase & - & + \\
\hline Reduction of nitrates & - & - \\
\hline Formation of H,S & - & - \\
\hline Formation of indole & + & + \\
\hline P- galactosidase & + & + \\
\hline Arginine dehydrolase & - & - \\
\hline Lysine decarboxylase & + & + \\
\hline Ornithine decarboxylase & + & + \\
\hline The use of citrate & - & - \\
\hline Urease & + & + \\
\hline Tryptophan deaminase & + & + \\
\hline Voges-Proskauer reaction & - & - \\
\hline Gelatinase & + & + \\
\hline The use of: Glucose (anaerobic) & + & + \\
\hline Mannitol & - & + \\
\hline Inositol, sorbitol & + & \\
\hline Rhamnose, melibiose, amygdalin, arabinose & + & \\
\hline
\end{tabular}

$*+$ the presence of the property, - the absence of the property.

by low resistance and competitiveness, even those that grow in optimal conditions. A number of assumptions have been put forward about the causes of this phenomenon, in particular, we are talking about climatic changes and hydrothermal stress, invasive infectious agents and pests, but so far each of the theories requires scientific confirmation [15, 33-34].

On the basis of the research carried out on stands with the participation of common oak within the Kyiv Polissya, we argue that the diseases we discovered by all symptomatic signs are systemic, vascular-parenchymal bacteriosis, known as bacterial dropsy of oak, which affects all tissues, plant parts and generative organs at all stages of ontogenesis, including self-seeding and seedlings.

We have noted the habitual manifestations of the bacterial dropsy of the common oak. In particular, the examined trees formed small forest disease centers, were characterized by an excessive «openwork» crown, as well as defoliation and death of 1-2 annual shoots. On the trunks, cracking of the bark was noted with streaks of gassy liquid and dark-colored mucus with a typical smell of oilyacid fermentation.
In some areas, cracks turn into depressed necrotic wet wounds. A wet black bast is visualized under the peridermis layer, down to the cambium. In the latter case, an ulcer forms on the trunk $[9,14$, 17, 35]. There are also water shoots on the trunks, which are another direct evidence of bacteriosis affecting oak trees.

According to the literature and our research, the causative agent of bacterial dropsy of tree species is the bacterium Lelliottia nimipressuralis (Carter 1945) Brady et al. 2013 [36] (outdated pathogen name Enterobacter nimipressuralis (Carter 1945)) Brenner et al. 1988 [14, 36-38].

Conclusions. Summarizing the results obtained, we can conclude that from the lesion, where under the bark in the area of the wound, dark brown areas of wood appeared against the background of healthy light-colored wood. By morphological and physiological-biochemical properties isolated bacterial isolates were identified by us as Lelliottia nimipressuralis (Carter 1945) [36] (outdated pathogen name - Enterobacter nimipressuralis (Carter 1945)) [32] - the causative agent of bacterial dropsy of oak. 
LELLIOTTIA NIMIPRESSURALIS

(CARTER 1945) BRADY ET AL. 2013 ЗБУДНИК БАКТЕРІАЛЬНОЇ ВОДЯНКИ ДУБА ЗВИЧАЙНОГО (QUERCUS ROBUR L.) В УKPAÏHI

І.М. Кульбанська, М.В. Швець ${ }^{2}$, А.Ф. Гойчук', Л.Г. Білявська ${ }^{4}$ В.П. Патика ${ }^{3}$

${ }^{1}$ Національний університет біоресурсів і природокористування Украӥни, вул. Генерала Родімщева, 19, Київ, 03041, Україна

${ }^{2}$ Поліський національний університет, вул. Старий бульвар, 7, Житомир, 10002, Україна

${ }^{3}$ Інституту мікробіології і вірусології ім. Д.К.Заболотного НАН України, вул. Академіка Заболотного, 154, Київ, 03143, Україна

${ }^{4}$ Полтавський державний аграрний університет,вул. Сковороди, 1/3, Полтава, 36000, Украӥна

Резюме

В статті наведена симптоматична характеристика досить поширеного на лісових деревних рослинах судинно-паренхіматозного бактеріозу, спричиненого збудником бактеріальної водянки. Показано, що характерною особливістю даного бактеріозу є формування різної форми та розмірів виразок, в місцях утворення яких спостерігається виділення темного, майже чорного, ексудату. Акцентується увага на тому, що при анатомічному дослідженні судинної системи дерев дуба звичайного помітне темне іiі забарвлення. Наразі спостерігається хронічне протікання хвороби 3 наявністю в кроні всихання окремих скелетних гілок. Встановлено, що збудником бактеріальної водянки є Lelliottia nimipressuralis, наведено iï фізіолого-біохімічні характеристики. Метою роботи є бактеріологічне дослідження зразків деревини з типовими ознаками ураження бактеріальною водянкою, дослідження морфологічних, культуральних і біохімічних властивостей збудника бактеріальної водянки дуба. Методи. В роботі використані класичні мікробіологічні, фітопатологічні, біохімічні, статистичні методи. За підозри на бактеріальну водянку використовували поєднані методи діагностики, за допомогою яких встановили етіологію захворювання: точний аналіз симптомів; ретельне мікроскопічне дослідження уражених частин рослин; виділення та ідентифікацію збудника з використанням тест-систем NEFERMtest24 MikroLaTE, ErbaLachema, API 20E, тощо. Результати. Нами відмічені габітуальні прояви бактеріальної водянки дуба звичайного. Із ураження, де під корою в районі виразки виявляли темно-коричневі ділянки деревини на фоні здорової деревини світлого кольору, виділені ізоляти бактерій, що за морфологічними і фізіолого-біохімічними властивостями ідентифіковані нами як Lelliottia nimipressuralis (Brady et al., 2013 ) - збудник бактеріальної водянки дуба (зараз Enterobacter nimipressuralis). Встановлено, що ізоляти, виділені з дуба звичайного, як і колекційний штам E. nimipressuralis 8791, є грамнегативними паличками. Показано, що досліджені бактерії $\epsilon$ факультативними анаеробами, використовують глюкозу як в аеробних, так і в анаеробних умовах. Не утворюють желатиназу і протопектиназу. Дають позитивну реакцію Фогес-Проскауера. Як єдине джерело вуглецевого живлення бактерії використовують глюкозу, арабінозу, рамнозу, маніт, амігдалин, мелібіозу. Бактерії не використовують інозит та сорбіт цитрат. Вони не утворюють індол i сірководень $\left(\mathrm{H}_{2} \mathrm{~S}\right)$, але здатні редукувати нітрати. У них присутня аргініндегідролаза, орнітиндекарбоксилаза, $\beta$-галактозидаза, але відсутні лізиндекарбоксилаза, уреаза. Висновки. Встановлено, що виявлена нами хвороба за всіма симптоматичними ознаками є системним, судинно-паренхіматозним бактеріозом, відомим як бактеріальна водянка дуба, яка уражає усі тканини, частини рослини і генеративні органи на всіх етапах онтогенезу. За морфологічними та фізіолого-біохімічними властивостями бактеріальних ізолятів, виділених нами в ході проведення досліджень, нами ідентифікований збудник бактеріальної водянки дуба Lelliottia nimipressuralis (Carter 1945).

Ключові слова: Lelliottia nimipressuralis, дуб звичайний, фітопатогенні бактерії і гриби, раптове відмирання, етіологія, патогенез, бактеріальна водянка. 
1. Press service of Volyn OULMG (2019, April 27). The problem of mass deforestation was discussed at the board of the State Forest Agency. URL: https://lisvolyn.gov.ua/?p=42381 (Date of application: 12.01.2021)

2. Oak drying is observed in Uzhhorod region (2020, April 2). URL: https://uzh-lishosp.com. ua/na-uzhhorodschyni-sposterihajetsya-vsyhannya-duba/ (Date of application: 15.12.2020)

3. Volyn oaks give oak (2011, July 6) URL: https:// www.openforest.org.ua/10489/ (Date of application: 15.12 .2020$)$

4. Oak Dropsy (2019, September 9). URL: https:// fastivlis.net/no_cache/novini/novina/article/ vodjanka-duba.html. (Date of application: 15.12.2020)

5. Kalinichenko NP. [Oak trees of Russia: monograph]. Moskva: VNIITslesresurs. 2000. 524529. Russian.

6. Molchanov AA. [The impact of anthropogenic factors on the forest]. Moskva: Nauka. 1978. 136. Russian.

7. Tsaralunga VV. [Cyclicity of accelerated withering away of oak]. Lesnoy vestnik. Moskva: MGUL. 2002; 2:31-35. Russian.

8. Selochnik N, Oszako T, Delatour C. Oak decline in the forest-steppe region of Russia. Recent advances on oak health in Europe. Warsaw. Poland. 2000; 83-89.

9. Vorontsov AI. [Forest pathology]. Moskva: Lesnaya promyshlennost'. 1978. 272. Russian.

10. Borodayevskiy LS. [Drying out of the forest in the Mayatskaya dacha of the Maetsky forestry of the Kharkiv region]. Lesnoy zhurnal. 1909; 6:688-711. Russian.

11. Polozhentsev PA, Savvin IM. [About the reasons for the withering away of oak forests]. Lesnoye khozyaystvo. 1976; 5:93-95. Russian.

12. Kostin SI. [Influence of precipitation on the growth of early and late oak]. Lesovedeniye. 1968; 2:80-83. Russian.

13. Izrail'skiy VP. [Bacterial plant diseases]. Moskva: Sel'khozgiz. 1952. 344. Russian.

14. Cherpakov VV. [Etiology of bacterial dropsy of woody plants]. Izvestiya Sankt-Peterburgskoy lesotekhnicheskoy akademii. 2017; 220:125-139. Russian.
15. Gvozdyak RI, Yakovleva LM. [Bacterial diseases of forest tree species]. Kyiv: Naukova Dumka; 1979. Ukrainian.

16. Goychuk AF, Gordienko MI, Gordienko NM, et al. Patologiya dibrov. Kyiv; 2004. 470 p. Ukrainian.

17. Grünwald NJ, Goss EM, Press CM. Phytophthora ramorum: a pathogen with a remarkably wide host range causing sudden oak death on oaks and ramorum blight on woody ornamentals. Molecular Plant Pathology. 2008; 9(6):729-740. doi:10.1111/j.1364-3703.2008.00500.x.

18. Frankel SJ. Sudden oak death and Phytophthora ramorum in the USA: a management challenge. Australasian Plant Pathology. 2008; 37(1):19-25. doi:10.1071/AP07088.

19. Brasier C, Denman S, Brown A, Webber J. Sudden oak death (Phytophthora ramorum) discovered on trees in Europe. Mycological Research. 2004; 108:1108-1110. doi:10.1017/S0953756204221244.

20. Davidson J, Werres S, Garbelotto M, Hansen E, Rizzo D. Sudden Oak Death and Associated Disaeses Caused by Phytophthora ramorum. Plant Health Progress. 2003; 23. doi:10.1094/PHP2003-0707-01-DG.

21. Tooley PW, Kyde KL. Susceptibility of Some Eastern Forest Species to Phytophthora ramorum. Plant Disease. 2007; 91(4):435-438. doi:10.1094/PDIS-91-4-0435.

22. Henry BW, Moses CS. An undescribed disease causing rapid dying of oak trees. Phytopathology. 1943; 33:18.

23. Juzwik J, Harrington T, Macdonald W, Appel D. The Origin of Ceratocystis fagacearum, the Oak Wilt Fungus. Annual review of phytopathology. 2008; 46:13-26. doi:10.1146/annurev.phyto.45.062806.094406.

24. Shcherbyn-Parfenenko AL. [Cancer and vascular diseases of hardwood]. Moskva; Leningrad: Goslesbumizdat. 1953. 89. Russian.

25. Yachyevsikii AA. [Plant diseases: phytopathology]. SPB. 1935. 192. Russian.

26. Goychuk AF, Drozda VF, Shvets MV, Kulbanska IM. Bacterial wetwood of silver birch (Betula pendula Roth): symptomology, etiology and pathogenesis. Folia Forestalia Polonica, Series A - 
Forestry. 2020; 62(3):145-159. DOI-10.2478 ffp-2020-0015.

27. Goychuk A, Kulbanska I, Shvets M. Bacteria associated with Pseudomonas syringae pv. savastanoi in the pathology of Fraxinus excelsior L. Mikrobiol Z. 2020; 82(3):22-34. doi: https://doi. org/10.15407/microbiolj82.03.022.

28. Klement E, Rudolph K, Sands S. Methods in phytobacteriology. Book. Akademiai Kiado. 1990; 568

29. Patyka VP, Pasichnyk LA, Dankevych LA, Moroz SM. Diagnosis of phytopathogenic bacteria. Guidelines. Kyiv; 2014; 76. Ukrainian.

30. Patyka VP, Pasichnyk LA, Gvozdyak RI, Petrichenko VF, et al. [Phytopathogenic bacteria. Methods of research. Monograph]. Volume 2; Vinnytsia: Windruck; 2017. Ukrainian.

31. Patyka VP, Pasichnyk LA, Butsenko LN, Petrichenko VF, et al. Express diagnostics of phytopathogenic bacteria and phytoplasmas in agrophytocenosis. Guidelines. Publisher Wydawnictwo I Drukarnia Świêxtego Krzyẑa, Opole, Poland, 2019; 78.

32. Brenner DJ, et al. Bergey's Manual of Systematic Bacteriology. New York: Springer Science; 2005.

33. Patyka VP, Pasichnyk LA. [Pathogenic bacteria: fundamental and applied aspects]. News of the Umansky National University of Gardening. 2014; 2:7-11. Ukrainian.
34. Fuchylo Y, Pasichnyk L, Patyka V, Kalinichenko A. Bioenergy willow: protection from the negative impact of biological factors. In: Renewable energy sources theory and practict. Vol. II, edited by Izabella Pietkun-Greber and Pawel Ratuszny-monograph; Opole, Kyiv, 2017. p. 144-162.

35 Alizadeh M. Bacterial Wetwood Disease. J Plant Chem and Ecophysiol. 2017; 2(1):1015.

36. Brady C, Cleenwerck I, Venter S, Coutinho T, De Vos P. Taxonomic evaluation of the genus Enterobacter based on multilocus sequence analysis (MLSA): proposal to reclassify E. nimipressuralis and E. amnigenus into Lelliottia gen. nov. as Lelliottia nimipressuralis comb. nov. and Lelliottia amnigena comb. nov., respectively. Syst Appl Microbiol. 2013; 36(5):309-319. doi:10.1016/j. syapm.2013.03.005.

37. Khodaygan P, Sedaghati E, Sherafati F. Isolation of Enterobacter nimipressuralis associated with bacterial wet wood from elm (Ulmus spp.) in Rafsanjan. Iranian Journal of Plant Pathology. 2011; 4(188): 481-482.

38. Liu S, Tang Y. Identification and Characterization of a New Enterobacter Onion Bulb Decay Caused by Lelliottia amnigena in China. Applied Microbiology: open access. 2016; 2. doi:10.4172/24719315.1000114/

Received 11.05.2021 